\title{
REVIEW: PARTIKULAT SEKUNDER DARI AKTIFITAS PENGECATAN
}

\section{A REVIEW: THE SECONDARY PARTICULATE MATTER FROM PAINTING}

\author{
Indri Santiasih ${ }^{\left.1^{*}\right)}$ \\ ${ }^{1)}$ Program Studi Teknik Keselamatan dan Kesehatan Kerja \\ Politeknik Perkapalan Negeri Surabaya \\ ${ }^{*}$ Email: indri.santiasih@gmail.com
}

\begin{abstract}
Abstrak
Proses pengecatan menghasilkan partikulat yang berasal dari penggunaan cat dan pelarut (solvent). Partikulat yang dihasilkan dari proses pengecatan dapat berupa partikulat primer dan sekunder. Partikulat sekunder merupakan hasil reaksi kimia antara volatile organic compound (VOC) dari cat dan pelarut (solvent) yang digunakan, dengan ozon di udara ambien. Proses pembentukan partikulat sekunder dari aktifitas pengecatan melalui proses nukleasi yang menghasilkan partikulat dengan diameter aerodinamis $<100 \mathrm{~nm}$. Ukuran partikulat yang sangat kecil meningkatkan resiko munculnya gangguan kesehatan pada manusia yang terpapar, baik pada paparan akut maupun kronis pada konsentrasi tertentu. Hal ini dikarenakan partikulat dapat dengan mudah menembus paru-paru bahkan dapat terdifusi dalam peredaran darah. Pengendalian terhadap variabelvariabel yang mempengaruhi konsentrasi partikulat antara lain VOC dan ozon merupakan salah satu upaya untuk menurunkan konsentrasi partikulat pada aktifitas pengecatan, selain pengendalian teknis seperti penggunaan heating, ventilating and air conditioning (HVAC).
\end{abstract}

Kata kunci : partikulat, VOC, ozon, gangguan kesehatan, pengecatan

\begin{abstract}
Particulate matter in painting activities, was produced by paint and solvent. It could be primary or secondary ones. The secondary particulate matter was a product from chemical reaction between volatile organic compound (VOC) from paint and solvent and ozone in ambient air. Particulate matter in painting was formed by nucleation process resulting aerodynamic diameter $<100 \mathrm{~nm}$. The size of particulate which was extremely small increased the risk of human health problems who was both acutely or chronically exposed in a specific particulate level. For the reason that it could easily penetrated to human lungs, moreover it could be difused to human blood. Originally, the controlling of variables which affected the particulate level such as VOC and ozone, was an attempt to decrease particulate level in painting, beside technical controlling instead like heating, ventilating and air conditioning (HVAC).
\end{abstract}

Keywords : particulate matter, VOC, ozone, health problems, painting 


\section{PENDAHULUAN}

Partikulat terdapat di udara ambien baik indoor maupun outdoor. Konsentrasi partikulat indoor berasal dari sumber di outdoor dan emisi langsung ke udara atau sebagai konversi dari gas precursor (seperti sulfur dioksida, oksida nitrogen, ammonia, dan non-methane volatile organic compounds) yang dilepaskan dari sumber alami dan anthropogenik (Atkinson et $a l ., 2010)$. Sumber antropogenik yang dimaksud termasuk proses pengecatan (Celebi and Vardar, 2008; Lazaridis et al., 2015).

Aktifitas pengecatan menghasilkan partikulat sekunder yang merupakan reaksi antara ozon dan gas precursor yang berasal dari penggunaan cat dan pelarut (solvent) (Hovorka and Braniš, 2011; Lazaridis et al., 2015). Pembentukan partikel ini berlangsung melalui proses nukleasi yang menghasilkan partikel dengan ukuran $<100 \mathrm{~nm}$ (Hovorka and Braniš, 2011; Kim et al., 2015; Lazaridis et al., 2015). Proses nukleasi terjadi karena adanya reaksi volatile organic compound (VOC) yang terdapat pada cat dan pelarut (solvent) dengan ozon di udara ambien (Celebi and Vardar, 2008; Nørgaard et al., 2014; Zhang et al., 2015). VOC merupakan gas precursor yang signifikan dihasilkan dari proses pengecatan (Celebi and Vardar, 2008).

Parameter partikulat yang potensial berbahaya adalah komposisi kimia dan ukuran partikel. Partikel dengan ukuran sangat halus (ultrafine) sangat berbahaya bagi manusia (Cusack et al., 2013; Hovorka and Braniš, 2011; Huang et al., 2011; Lazaridis et al., 2015; Vu et al., 2015). Hal ini dikarenakan partikel ini dapat masuk dengan mudah ke dalam saluran pernafasan manusia (Pope III and Dockery, 2006).

Dampak kesehatan yang ditimbulkan oleh partikel sangat halus (ultrafine) antara lain adalah penyakit kardiovaskuler, gangguan pernafasan dan kanker paru-paru (Karottki et al., 2014; Knibbs et al., 2011; Pope III and Dockery, 2006; Spilak et al., 2014). Partikel sangat halus
$(<100 \mathrm{~nm})$ terdeposit dalam tracheobronchiale bahkan partikel ini dapat mencapai alveoli paru dan terdifusi kedalam aliran darah, sehingga paparan partikel erat kaitannya dengan penyakit saluran pernafasan dan sistem peredaran darah (Franck et al., 2011; Karottki et al., 2014; Pope et al., 2009; Wu et al., 2014; Zhao et al., 2010).

\section{Karakteristik Partikulat dari Pengecatan.}

Karakteristik fisik dan kimiawi partikulat dapat ditentukan dari perilaku atmosferik yang memberikan informasi penting mengenai sumber partikel (Khotai et al., 2009). Dua parameter partikulat yang potensial berbahaya adalah komposisi kimia dan ukuran partikulat.

\subsection{Karakteristik Fisik}

Bentuk partikulat merupakan aspek fisik yang menyebabkan gangguan kesehatan (Davidson, 2005). Shandilya and Kumar (2010) menemukan adanya hubungan antara bentuk partikel dengan komponen kimia partikulat.

Partikulat sekunder dari aktifitas pengecatan merupakan partikulat sangat halus dengan diameter partikel $<100 \mathrm{~nm}$ yang terbentuk melalui proses nukleasi (Lamorena et al., 2007). Diamater partikel (dp) di atmosfer ada 4 tipe berdasarkan proses pembentukannya, yaitu partikulat nukleasi (dp $<30 \mathrm{~nm}$ ), partikulat aitken $(30 \mathrm{~nm}<\mathrm{dp}<100 \mathrm{~nm})$, partikulat akumulasi $(100 \mathrm{~nm}<\mathrm{dp}<1 \mathrm{~mm})$ dan partikulat kasar (dp > $1 \mathrm{~mm})$ (Hussein et al., 2005).

Partikulat sangat halus (ultrafine) perlu mendapat perhatian serius berdasarkan distribusi ukuran partikulat, karena merupakan diameter kunci penentu deposisi partikulat di paru-paru (Vu et al., 2015). Partikulat ini merupakan partikel paling berbahaya bagi manusia karena dapat menembus saluran pernafasan manusia dengan mudah sehingga memberikan dampak yang kompleks pada tubuh manusia antara lain gangguan system peredaran darah, system pernafasan, kanker paru (Pope III and Dockery, 2006). 


\subsection{Karakteristik Kimia}

Komposisi partikulat secara umum termasuk sulfat, nitrat, ammonium, dan ion organik lain (seperti ion sodium, potassium, kalsium, magnesium dan klorida), elemen karbon, serpihan material, partikel yang terikat air dan logam (termasuk cadmium, copper, nikel, vanadium dan zinc). Komposisi kimia berpengaruh signifikan terhadap derajad kesehatan seiring dengan penambahan konsentrasi dari partikulat (Baulig et al., 2009; Gualtieri et al., 2010; Perrone et al., 2013). Hal ini membuktikan bahwa konsentrasi partikulat sendiri tidak dapat menjelaskan dampak kesehatan yang ditimbulkan, karena partikulat tidak spesifik secara kimiawi.

Partikulat merupakan kombinasi yang kompleks dan heterogen dari beberapa partikel. Partikulat berasal dari sumber yang tidak terhitung yang mempunyai komposisi kimia bervariasi tergantung tempat dan waktu, yang menunjukkan tidak hanya variasi dari sumber, tetapi juga efek proses atmosferik (Loomis et al., 2013). Sedangkan komponen partikulat yang berinteraksi dengan ukuran partikulat yang menyebabkan gangguan kesehatan, masih membutuhkan klarifikasi lebih lanjut. Beberapa kajian telah dilakukan terhadap paparan jangka pendek pada penelitian in vitro dengan pengambilan sampel polusi udara dan hasilnya relevan secara toksikologi dengan karakteristik physicochemical (Abbas et al., 2009; Billet et al., 2007).

Komposisi partikulat ditemukan mengandung beberapa senyawa termasuk elemen karbon, bahan pelapis (coating), logam (termasuk cadmium, nikel, vanadium, copper dan zinc) serta polycyclic aromatic hydrocarbon $(\mathrm{PAH})$ (Cheung et al., 2011). Beberapa peneliti menemukan bahwa senyawa VOC dihasilkan dari proses pengecatan. Kura (1998) meneliti bahwa VOCs dan hazardous air pollutants (HAPs) dihasilkan dari proses pengecatan. Houang et al. (2001) mempelajari bahwa pengendalian terhadap polutan organik volatile dari industri dan mempelajari efek VOC terhadap kesehatan. Malherbe and Mandin (2007) meneliti emisi VOC selama pengecatan outdoor yang meningkatkan resiko penyakit. Norback et al. (1995) mengidentifikasi dan mengukur paparan VOC di indoor selama pengecatan dengan cat berbasis air. Guo et al. (1998) mengembangkan model transfer massa yang baru untuk estimasi emisi VOCs individual pada proses pemberian lapisan. Guo and Murray (2000) menghitung variasi parameter emisi dan estimasi konsentrasi total VOC indoor. Baoqing and Chang (2004) menunjukkan model analisis baru untuk emisi VOC pada material kering gedung. $\mathrm{Xu}$ and Zhang (2004) mengembangkan solusi analitik model baru, yang dapat diterapkan untuk menghitung emisi VOCs dari material kering bangunan satu lapisan dan distribusi VOC langsung di dalam material. Pendekatan inovatif penilaian ketidakpastian yang dikenal dengan sistem numeral, unit, spread, assessment, and pedigree (NUSAP) (Van der Sluijs et al., 2005). Metode ini digunakan untuk menilai ketidakpastian emisi VOC secara kualitatif dan kuantitatif dari cat. Qian et al. (2007) mengembangkan korelasi emisi VOC dari material kering bangunan. Schieweck and Bock (2015) melakukan evaluasi pelarut alternatif yang mempunyai bau menyengat pada proses pembersihan manual pada aktifitas pengecatan dan pengemasan, termasuk penggunaan penggosok dengan media plastik untuk menghilangkan cat. Dobson (1996) merekomendasikan teknik terbaik untuk mengurangi emisi VOC pada proses pengecatan mobil. Darvin (1998) melakukan desain paint booth untuk meminimalisir emisi VOC dari proses finishing. Pierucci (2005) melakukan penelitian tentang proses inovatif yang berkelanjutan berdasarkan absorbsi emisi udara dari proses pemberian lapisan, yang menghasilkan evaporasi pelarut organik khususnya VOC. Malherbe and Mandin (2007) meneliti efek pengecatan outdoor pada kesehatan manusia di perkapalan.

\section{Pembentukan Partikulat Sekunder.}

Partikel sangat halus (ultrafine) dihasilkan melalui sumber primer (aktifitas manusia) 
(Glytsos et al., 2010a) dan adanya reaksi kimia dari gas precursor (Chen and Hopke, 2009; Huang et al., 2012). Reaksi kimia merupakan sumber lain yang menghasilkan partikel sekunder pada tekanan yang rendah (Weschler, 2009). Partikel sekunder yang dihasilkan merupakan partikel nukleasi yang homogen. Mekanisme reaksi kimia pembentukan partikel yang berlangsung di indoor sama dengan yang terjadi di outdoor, hanya saja tanpa sinar ultra violet (UV) (Cusack et al., 2013; Huang et al., 2012; Wang and Waring, 2014).

\subsection{Partikulat Sekunder dari Aktifitas Pengecatan}

Karakteristik partikel untuk masing-masing aktifitas emisi berhubungan erat dengan sumber primer, yaitu pengecatan (Glytsos et al., 2010b; Hussain et al., 2011; Semple et al., 2012) Sedangkan laju emisi atau konsentrasi partikel sangat halus (ultrafine) meningkat signifikan selama aktifitas tersebut. Emisi bahan kimia indoor dari material bangunan, produk rumah tangga dan furnitur mendorong terbentuknya aerosol organik sekunder (Aoki and Tanabe, 2007; Uhde and Salthammer, 2007). Senyawa semivolatile yang ditemukan di indoor terbukti berasal dari beberapa sumber (Weschler and Nazaroff, 2008). Material pengecatan terdapat pada sumber yang sangat umum dan mengandung senyawa VOC (Weschler, 2009). Emisi dari material basah seperti cat didominasi evaporasi pada awalnya dan difusi internal setelah itu (Zhang and Niu, 2003). Partikel sangat halus terbentuk selama terjadi reaksi antara VOC berasal dari produk cat dan ozon di udara ambient (Fan et al., 2005). Penelitian ini menjelaskan juga bahwa VOCs dapat menjadi material precursor. Partikel sangat halus (ultrafine) ditemukan berasal dari pengecatan dimana di tempat yang sama terdapat ozon (Betha et al., 2011; Hovorka and Braniš, 2011; Quang et al., 2013). Quang et al. (2013) meneliti proses nukleasi di dalam gedung yang besar, tetapi proses ini menghasilkan partikel outdoor yang ditransportasikan ke indoor gedung melalui laju pertukaran udara yang tinggi. Vartiainen et al. (2006) meneliti bahwa formasi partikel indoor merupakan hasil dari oksidasi Dlimonene. Sedangkan menurut (Betha et al., 2011), formasi partikel sangat halus (ultrafine) terbentuk karena oksidasi VOC dari stimulasi ozon. Hovorka and Branis (2011) meneliti hubungan proses nukleasi pada konstruksi koridor yang sedang dilakukan pengecatan semprot (spray). VOC yang dihasilkan dari proses pengecatan lebih besar (karena proses pembentukan partikel sangat halus (ultrafine) lebih banyak) dibandingkan dengan adanya penetrasi partikel dari outdoor. Hal ini dikarenakan laju pertukaran udara rendah dan waktu tinggal partikel yang tinggi di dalam gedung. Penelitian ini merupakan analisis proses pembentukan partikel baru dari proses pengecatan yang dilakukan di dalam laboratorium.

\subsection{Faktor yang Berpengaruh Terhadap Emisi Partikulat}

Beberapa hal yang berpengaruh terhadap emisi partikulat antara lain material bangunan, adanya ozon di udara ambien, ventilasi dan adanya gas precursor.

\subsubsection{Material Bangunan}

Cheng et al. (2015) meneliti tentang material bangunan yang merupakan kontributor utama dalam menghasilkan VOC. Beberapa penelitian menunjukkan sumber emisi partikulat indoor misalnya aldehide dan BTEX indoor seperti hardwood, plywood, pelapis lantai, material dekorasi, adhesive, cat, varnish, (Marchand et al., 2006; Shinohara et al., 2009). n- VOC diproduksi dari beberapa material bangunan yang mempunyai tekanan uap lebih besar dari 0,1 $\mathrm{mmHg}$ pada kondisi standar $\left(20^{\circ} \mathrm{C}\right.$ dan 760 mmHg yang merupakan sumber utama emisi partikulat indoor (Marion et al., 2011; Xu et al., 2016). Menurut Cheng et al. (2015) material bangunan yang kasar dan berpori bereaksi dengan ozon lebih besar dibandingkan material halus dan tidak berpori. Emisi sekunder pada penelitian ini menunjukkan bahwa konsentrasi 
ozon yang besar akan meningkatkan konsentrasi karbonil seperti formaldehyde dan acetyldehyde yang akan menimbulkan dampak kesehatan pada manusia. Material bangunan (plafon dengan serat mineral dan plafon dengan serat mineral ramah lingkungan) memberikan emisi partikel sekunder yang kecil pada konsentrasi ozon yang besar.

Hal serupa juga ditemukan oleh Lin and Hsu (2015) bahwa terdapat kecenderungan kecepatan deposisi ozon lebih besar pada material yang kasar dan berpori jika dibandingkan dengan material yang halus dan tidak berpori

Beberapa material bangunan indoor bereaksi dan sekaligus mengkonsumsi ozon secara pasif, misalnya lantai dari vinyl, dinding batu bata dan gypsum (Hoang et al., 2009). Tetapi komposisi material bangunan akan menghasilkan partikulat sekunder yang berbeda dengan partikulat yang merupakan hasil reaksi ozon dan produk seperti karpet, cat, kulit, rambut dan pakaian (Bekö et al., 2007; Coleman et al., 2008; Pandrangi and Morrison, 2008; W. Zhao et al., 2007). Olehkarena itu pemilihan material bangunan di dalam ruangan harus diperhatikan sebagai upaya menurunkan konsentrasi partikel indoor.

\subsubsection{Ozon di Udara Ambien}

Beberapa penelitian mengkaji mengenai pembentukan partikel baru yang merupakan hasil reaksi antara VOC dan ozon (Hovorka and Braniš, 2011; Lamorena and Lee, 2008; Nørgaard et al., 2014; Wang and Waring, 2014). Adanya ozon di dalam ruangan lebih dikarenakan alasan efisiensi energy tetapi dalam penerapan hasilnya kurang bagus (Huang et al., 2011).

Reaksi kimia yang menghasilkan partikulat terjadi antara ozon dan volatile karbonil dan gas precursor yang lain (Aoki and Tanabe, 2007; Wang and Morrison, 2006). Mekanisme reaksi antara ozon dan karbonil terdapat pada Gambar 1.

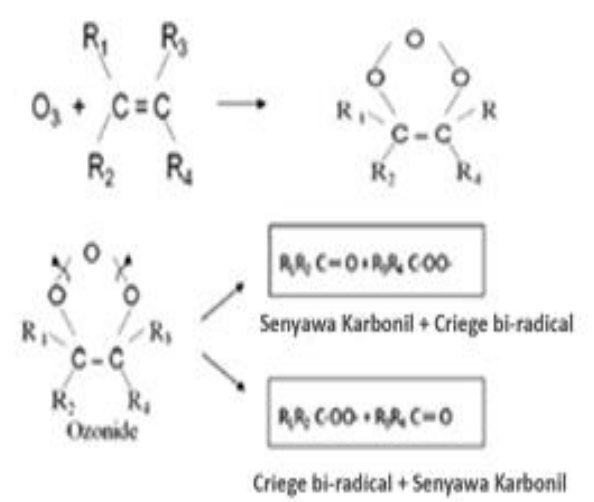

Gambar 1. Mekanisme Reaksi antara Ozon dan Karbonil

Sumber : Cheng et al. (2015)

Weschler et al. (1992) meneliti bahwa adanya ozon di udara ambien $\left(60-100 \mathrm{mg} / \mathrm{m}^{3}\right)$ dan terdapat karpet di dalam reaktor stainless steel, konsentrasi VOC fase gas termasuk styrene, 4$\mathrm{VCH}$ and 4-PCH menurun secara signifikan ketika konsentrasi aldehide $\left(\mathrm{C}_{1}-\mathrm{C}_{10}\right)$ meningkat. Total konsentrasi VOC juga meningkat signifikan pada emisi sekunder termasuk $\mathrm{C}_{1}$ (formaldehyde), $\mathrm{C}_{2}$ (Acetyldehide) dan $\mathrm{C}_{5}-\mathrm{C}_{10}$ (pentanal - decanal) aldehyde dari karpet, dinding, lantai dan langit-langit pada kenaikan konsentrasi ozon (Wang and Morrison, 2006). Huang et al. (2012) melakukan penelitian dengan reaktor dari panel kayu yang di cat, menemukan bahwa konsetrasi formaldehyde pada reactor meningkat $215,8 \%$ dengan penambahan konsentrasi ozon 200 ppb dan waktu reaksi 3 jam.

Hoang et al. (2009) melakukan penelitian mengenai upaya penyisihan ozon dengan beberapa material bangunan ramah lingkungan. Hasilnya adalah langit-langit dengan bahan perlite-based merupakan material bangunan yang paling reaktif terhadap ozon, dengan kecepatan deposisi $0,05 \mathrm{~cm} / \mathrm{s}$, lebih besar 2 kali dibandingkan dengan material dari gandum dan bunga matahari, lebih besar 10 kali dibandingkan dengan material dari keramik dan bambu, dan lebih besar 50 kali dibandingkan dengan material dari bambu yang dilapisi UV. 


\subsubsection{Gas Precursor}

Reaksi kimia di indoor pada prinsipnya mempunyai mekanisme yang sama dengan reaksi kimia di outdoor, hanya saja terdapat perbedaan boundary. Sumber emisi partikulat sekunder berasal dari proses nukleasi homogen gas precursor (Cusack et al., 2013; Huang et al., 2012; Wang and Waring, 2014). Reaksi kimia ini terjadi di udara ambien karena tidak adanya preexisting surface (Jacobson, 2002). Gas precursor yang terdapat pada material cat adalah VOC (Celebi and Vardar, 2008; Lazaridis et al., 2015; Malherbe and Mandin, 2007) yang akan membentuk partikel sekunder jika bereaksi dengan ozon di udara ambien (Cheng et al., 2015; Lazaridis et al., 2015).

Gall et al. (2013) menemukan bahwa terjadi penurunan molar karbonil (yang dihasilkan dari reaksi antara ozon dan karpet daur ulang) ketika terjadi peningkatan kelembaban relatif. Sedangkan deposisi ozon pada material karpet daur ulang tidak terjadi perubahan yang cukup besar.

Lamble et al. (2011) melakukan penelitian terhadap beberapa material yang ada di dalam ruangan antara lain lantai keramik, lantai bambu, karpet, lantai dan dinding plester lempung, cat latex, cat lempung, cat kolagen, langit-langit perlite, langit-langit fiberglass, langit-langit serat mineral dan lain-lain. Material tesebut menghasilkan emisi karbonil dan sekaligus mempunyai kemampuan untuk menyisihkan ozon. Hasil penelitian menunjukkan bahwa semua material menghasilkan produk aldehyde jenuh dari $\mathrm{C}_{1}$ sampai dengan $\mathrm{C}_{12}$ ditambah acetone dari range yang tidak terdeteksi sampai dengan 0,70. Sedangkan kecepatan deposisi ozon tertinggi adalah pada material dinding plester lempung yaitu $5 \mathrm{~m} / \mathrm{jam}$.

\subsubsection{Ventilasi}

Ozon dapat dikontrol menggunakan filtrasi dengan activated carbon pada ventilasi mekanis (Jurelionis et al., 2015). Filter heating, ventilating and air conditioning (HVAC) mampu menurunkan konsentrasi ozon di dalam ruangan meskipun penurunan konsentrasi ozon tidak terlalu besar (P. Zhao et al., 2007).

Faulkner et al. (2015) menemukan bahwa dengan peningkatan laju ventilasi, konsentrasi partikulat di dalam ruangan menurun secara linier, sedangkan konsentrasi partikulat di outlet menurun secara eksponensial. Efek laju ventilasi lebih besar pada partikel dengan ukuran 1,9 $\mu \mathrm{m}$ dibandingkan pada partikel dengan 5,4 $\mu \mathrm{m}$ dan $7,9 \mu \mathrm{m}$. Tetapi pergantian udara per jam (air change per Hour/ACH) sebesar 6 kali, tidak dapat menurunkan konsentrasi partikel di dalam ruangan pada berbagi ukuran partikel.

Menurut Faulkner et al. (2013), konsentrasi partikulat tidak terpengaruh secara signifikan oleh ketinggian pengambilan sampel, laju dust feed, temperatur, tekanan udara, dan kelembaban. Konsentrasi partikulat di dalam ruangan sangat bervariasi pada $\mathrm{ACH}$ tertentu. Hal ini dikarenakan sistem pergantian udara tidak mampu menjaga $\mathrm{ACH}$ sesuai dengan target yang diinginkan.

\section{Dampak Partikulat terhadap Kesehatan Manusia}

Partikel yang berukuran sangat halus (ultrafine) (<100 nm) adalah partikel paling berbahaya bagi manusia, karena dapat masuk dengan mudah ke dalam saluran pernafasan manusia. Lu et al. (2014) melakukan analisis karakteristik physicochemical partikulat dan toksikologi termasuk cytotoxicity, oxidativestress dan peradangan. Mekanisme yang terjadi pada polusi udara karena partikulat masih belum jelas, tetapi perkembangan dan/atau memburuknya kondisi oksidatif dan sekresi cytokine telah ditemukan sebagai penyebab utama (Baulig et al., 2009; Gualtieri et al., 2010; Longhin et al., 2013; Sangiorgi et al., 2013) Excessive Production of Reactive Oxygen Species (ROS) merupakan upaya detoksifikasi pertahanan diri sel anti oksidan berupa kejadian yang berhubungan dengan peradangan dan menghasilkan respon akut memburuknya peradangan di paru-paru (Lonkar and Dedon, 2011). 
Dampak kesehatan yang ditimbulkan antara lain adalah penyakit kardiovaskuler, pernafasan, dan kanker paru-paru, yang berhubungan langsung dengan paparan partikel sangat halus (ultrafine) (Pope III and Dockery, 2006). Kajian mengenai paparan partikulat 2.5-0.3 jangka pendek dilakukan dengan konsentrasi dan/atau variabel waktu toksikologi pada beberapa variasi model target paru-paru manusia (Abbas et al., 2010; Dagher et al., 2007; Dergham et al., 2012; Garçon et al., 2006). Paparan partikulat pada level tinggi dapat menyebabkan berat badan bayi lahir rendah, bahkan kematian bayi dan janin (Guaita et al., 2011). Kajian epidemiologi di USA melakukan penelitian dengan menghubungkan antara polusi partikulat dengan diabetes pada dewasa dengan faktor resiko seperti obesitas dan etnik (Pearson et al., 2010). Paparan partikulat ditemukan mempengaruhi perkembangan paru-paru anak termasuk gangguan fungsi paru dan paru-paru yang tidak berkembang (Brauer et al., 2012).

Beberapa kajian menunjukkan bahwa faktor kimia berpengaruh terhadap kesehatan manusia secara toksikologi, kemudian mengindikasikan variasi komposisi yang berhubungan dengan perbedaan tempat dan waktu yang dapat menyebabkan gangguan kesehatan pada manusia yang terpapar (Loomis et al., 2013). Studi epidemiologi menunjukkan bahwa level konsentrasi partikulat berkontribusi terhadap angka kematian dan angka kesakitan pada saluran pernafasan, disfungsi paru-paru, penyakit jantung dan kanker (Ferro et al., 2004; Gauderman et al., 2004). Efek kesehatan jangka pendek yang ditimbulkan masih belum dipahami secara pasti (Ferro et al., 2004). Hal ini karena efek kesehatan kronis yang berhubungan dengan paparan jangka pendek yang berulang, yang akan meningkatkan level partikulat. Studi epidemiologi yang lain menunjukkan peningkatan angka kematian karena penyakit saluran pernafasan dan kardiovaskuler selama dan setelah paparan jangka pendek partikulat dengan konsentrasi tinggi (Samet et al., 2000).

Paparan jangka pendek dengan konsentrasi tinggi memicu serangan jantung pada orang-orang yang rentan (Peters et al., 2001). Hasil penelitian ahli lain menjelaskan paparan jangka pendek partikulat berhubungan secara statistik dengan peningkatan angka kesakitan. Paparan jangka pendek juga menunjukkan hubungan yang signifikan terhadap level polusi partikulat dan terbukti menimbulkan dampak terhadap kesehatan. Tetapi penelitian ini tidak dapat menentukan no-effect concentration (NEC) atau batas atas konsentrasi yang diperkenankan (Schwartz, 2001). Hal ini membuktikan bahwa baik paparan jangka pendek maupun jangka panjang menyebabkan efek kesehatan yang serius (Ferro et al., 2004; Gauderman et al., 2004).

\section{KESIMPULAN}

Partikulat sekunder yang dihasilkan dari pengecatan merupakan partikel sangat halus (ultrafine) yang terbentuk dari reaksi kimia. Reaksi kimia pembentukan partikel sekunder ini adalah nukleasi, yang menghasilkan partikel dengan diameter aerodinamik $<100 \mathrm{~nm}$. Reaksi ini berlangsung ketika adanya gas precursors dari cat dan pelarut (solvent) yaitu VOC dan ozon di udara ambient. Komposisi kimia partikulat sangat bervariasi, tergantung sumber emisi. Komposisi kimia sangat menentukan derajad keparahan pada manusia yang terpapar. Material bangunan menghasilkan emisi VOC dan sekaligus mempunyai kemampuan untuk menyisihkan ozon di udara ambient. Ventilasi mekanis yang memadai mampu menurunkan konsentrasi VOC dan ozon, untuk meminimalisir partikel sekunder. Partikel sangat halus sangat berbahaya bagi kesehatan manusia, karena dapat dengan mudah menembus paru-paru, bahkan dapat terdifusi dalam aliran darah, sehingga dapat mengakibatkan gangguan serius.

\section{DAFTAR PUSTAKA}

Abbas, I., Garçon, G., Saint-Georges, F., Billet, S., Verdin, A., Gosset, P., Mulliez, P., Shirali, P., (2010). Occurrence of molecular abnormalities of cell cycle in L132 cells after in vitro short-term exposure to air pollution PM2.5. Chem. Biol. Interact. 188, 558-565. 
Abbas, I., Saint-Georges, F., Billet, S., Verdin, A., Mulliez, P., Shirali, P., Garçon, G., (2009). Air pollution particulate matter (PM2.5)-induced gene expression of volatile organic compound and/or polycyclic aromatic hydrocarbonmetabolizing enzymes in an in vitro coculture lung model. Toxicol. Vitr. 23, 3746.

Aoki, T., Tanabe, S., (2007). Generation of submicron particles and secondary pollutants from building materials by ozone reaction. Atmos. Environ. 41, 3139-3150.

Atkinson, R.W., Fuller, G.W., Anderson, H.R., Harrison, R.M., Armstrong, B., (2010). Urban ambient particle metrics and health: a time-series analysis. Epidemiology 21, 501-11.

Baulig, A., Singh, S., Marchand, A., Schins, R., Barouki, R., Garlatti, M., Marano, F., Baeza-Squiban, A., (2009). Role of Paris PM2.5 components in the pro-inflammatory response induced in airway epithelial cells. Toxicology 261, 126-135.

Bekö, G., Clausen, G., Weschler, C.J., (2007). Further studies of oxidation processes on filter surfaces: Evidence for oxidation products and the influence of time in service. Atmos. Environ. 41, 5202-5212.

Betha, R., Selvam, V., Blake, D.R., Balasubramanian, R., (2011). Emission characteristics of ultrafine particles and volatile organic compounds in a commercial printing center. J. Air Waste Manag. Assoc. 61, 1093-101.

Billet, S., Garçon, G., Dagher, Z., Verdin, A., Ledoux, F., Cazier, F., Courcot, D., Aboukais, A., Shirali, P., (2007). Ambient particulate matter (PM2.5): Physicochemical characterization and metabolic activation of the organic fraction in human lung epithelial cells (A549).
Environ. Res. 105, 212-223.

Brauer, M., Amann, M., Burnett, R.T., Cohen, A., Dentener, F., Ezzati, M., Henderson, S.B., Krzyzanowski, M., Martin, R. V, Van Dingenen, R., van Donkelaar, A., Thurston, G.D., (2012). Exposure assessment for estimation of the global burden of disease attributable to outdoor air pollution. Environ. Sci. Technol. 46, 652-60.

Celebi, U.B., Vardar, N., (2008). Investigation of VOC emissions from indoor and outdoor painting processes in shipyards. Atmos. Environ. 42, 5685-5695.

Chen, X., Hopke, P.K., (2009). A chamber study of secondary organic aerosol formation by linalool ozonolysis. Atmos. Environ. 43, 3935-3940.

Cheng, Y., Lin, C.-C., Hsu, S.-C., (2015). Comparison of conventional and green building materials in respect of VOC emissions and ozone impact on secondary carbonyl emissions. Build. Environ. 87, 274-282.

Cheung, H.C., Morawska, L., Ristovski, Z.D., (2011). Observation of new particle formation in subtropical urban environment. Atmos. Chem. Phys. 11, 3823-3833.

Coleman, B.K., Destaillats, H., Hodgson, A.T., Nazaroff, W.W., (2008). Ozone consumption and volatile byproduct formation from surface reactions with aircraft cabin materials and clothing fabrics. Atmos. Environ. 42, 642-654.

Cusack, M., Alastuey, A., Querol, X., (2013). Case studies of new particle formation and evaporation processes in the western Mediterranean regional background. Atmos. Environ. 81, 651-659.

Dagher, Z., Garçon, G., Billet, S., Verdin, A., Ledoux, F., Courcot, D., Aboukais, A., 
Shirali, P., (2007). Role of nuclear factorkappa B activation in the adverse effects induced by air pollution particulate matter (PM2.5) in human epithelial lung cells (L132) in culture. J. Appl. Toxicol. 27, 28490.

Darvin, C.H., Proffitt, D., Ayer, J., (1998). Paint spray booth design using recirculation/partitioning ventilation. Environ. Prog. 17, 199-202.

Deng, B., Kim, C.N., (2004). An analytical model for VOCs emission from dry building materials. Atmos. Environ. 38, 1173-1180.

Dergham, M., Lepers, C., Verdin, A., Billet, S., Cazier, F., Courcot, D., Shirali, P., Garçon, G., (2012). Prooxidant and proinflammatory potency of air pollution particulate matter $\left(\mathrm{PM}_{2 \cdot 5-0.3}\right)$ produced in rural, urban, or industrial surroundings in human bronchial epithelial cells (BEAS2B). Chem. Res. Toxicol. 25, 904-19.

Dobson, I.D., (1996). Life cycle assessment for painting processes: putting the VOC issue in perspective. Prog. Org. Coatings 27, 55-58.

Fan, Z., Weschler, C.J., Han, I.-K., Zhang, J. (Jim), (2005). Co-formation of hydroperoxides and ultra-fine particles during the reactions of ozone with a complex VOC mixture under simulated indoor conditions. Atmos. Environ. 39, 5171-5182.

Faulkner, W.B., Memarzadeh, F., Riskowski, G., Hamilton, K., Chang, C.-Z., Chang, J.-R., (2013). Particulate concentrations within a reduced-scale room operated at various air exchange rates. Build. Environ. 65, 71-80.

Faulkner, W.B., Memarzadeh, F., Riskowski, G., Kalbasi, A., Ching-Zu Chang, A., (2015). Effects of air exchange rate, particle size and injection place on particle concentrations within a reduced-scale room. Build. Environ. 92, 246-255.
Ferro, A.R., Kopperud, R.J., Hildemann, L.M., (2004). Source Strengths for Indoor Human Activities that Resuspend Particulate Matter. Environ. Sci. Technol. 38, 17591764.

Franck, U., Odeh, S., Wiedensohler, A., Wehner, B., Herbarth, O., (2011). The effect of particle size on cardiovascular disorders The smaller the worse. Sci. Total Environ. 409, 4217-4221.

Gall, E., Darling, E., Siegel, J.A., Morrison, G.C., Corsi, R.L., (2013). Evaluation of three common green building materials for ozone removal, and primary and secondary emissions of aldehydes. Atmos. Environ. 77, 910-918.

Garçon, G., Dagher, Z., Zerimech, F., Ledoux, F., Courcot, D., Aboukais, A., Puskaric, E., Shirali, P., (2006). Dunkerque City air pollution particulate matter-induced cytotoxicity, oxidative stress and inflammation in human epithelial lung cells (L132) in culture. Toxicol. Vitr. 20, 519528.

Gauderman, W.J., Avol, E., Gilliland, F., Vora, H., Thomas, D., Berhane, K., McConnell, R., Kuenzli, N., Lurmann, F., Rappaport, E., Margolis, H., Bates, D., Peters, J., (2004). The effect of air pollution on lung development from 10 to 18 years of age. N. Engl. J. Med. 351, 1057-67.

Glytsos, T., Ondráček, J., Džumbová, L., Kopanakis, I., Lazaridis, M., (2010)a. Characterization of particulate matter concentrations during controlled indoor activities. Atmos. Environ. 44, 1539-1549.

Glytsos, T., Ondráček, J., Džumbová, L., Kopanakis, I., Lazaridis, M., (2010)b. Characterization of particulate matter concentrations during controlled indoor activities. Atmos. Environ. 44, 1539-1549. 
Guaita, R., Pichiule, M., Maté, T., Linares, C., Díaz, J., (2011). Short-term impact of particulate matter $(\operatorname{PM}(2.5))$ on respiratory mortality in Madrid. Int. J. Environ. Health Res. 21, 260-74.

Gualtieri, M., Øvrevik, J., Holme, J.A., Perrone, M.G., Bolzacchini, E., Schwarze, P.E., Camatini, M., (2010). Differences in cytotoxicity versus pro-inflammatory potency of different PM fractions in human epithelial lung cells. Toxicol. Vitr. 24, 2939.

Guo, H., Murray, F., (2000). Characterization of total volatile organic compound emissions from paints. Clean Prod. Process. 2, 0028 0036.

Guo, Z., Sparks, L.E., Tichenor, B.A., Chang, J.C.S., (1998). Predicting the emissions of individual VOCs from petroleum-based indoor coatings. Atmos. Environ. 32, 231237.

Hoang, C.P., Kinney, K.A., Corsi, R.L., (2009). Ozone removal by green building materials. Build. Environ. 44, 1627-1633.

Houang, E.T., Chu, Y.W., Leung, C.M., Chu, K.Y., Berlau, J., Ng, K.C., Cheng, A.F., (2001). Epidemiology and infection control implications of Acinetobacter spp. in Hong Kong. J. Clin. Microbiol. 39, 228-34.

Hovorka, J., Braniš, M., (2011). New particle formation and condensational growth in a large indoor space. Atmos. Environ. 45, 2736-2749.

Huang, H.-L., Tsai, T.-J., Hsu, N.-Y., Lee, C.-C., Wu, P.-C., Su, H.-J., (2012). Effects of essential oils on the formation of formaldehyde and secondary organic aerosols in an aromatherapy environment. Build. Environ. 57, 120-125.

Huang, Y., Ho, K.F., Ho, S.S.H., Lee, S.C., Yau, P.S., Cheng, Y., (2011). Physical parameters effect on ozone-initiated formation of indoor secondary organic aerosols with emissions from cleaning products. J. Hazard. Mater. 192, 17871794.

Hussain, M., Russo, N., Saracco, G., (2011). Photocatalytic abatement of VOCs by novel optimized $\mathrm{TiO} 2$ nanoparticles. Chem. Eng. J. 166, 138-149.

Hussein, T., Hämeri, K., Heikkinen, M.S.A., Kulmala, M., (2005). Indoor and outdoor particle size characterization at a family house in Espoo-Finland. Atmos. Environ. 39, 3697-3709.

Jacobson, M.Z., (2002). Atmospheric Pollution: History, Science and Regulation. Cambridge University Press, Cambridge.

Jurelionis, A., Gagytė, L., Prasauskas, T., Čiužas, D., Krugly, E., Šeduikyte, L., Martuzevičius, D., (2015). The impact of the air distribution method in ventilated rooms on the aerosol particle dispersion and removal: The experimental approach. Energy Build. 86, 305-313.

Karottki, D.G., Bekö, G., Clausen, G., Madsen, A.M., Andersen, Z.J., Massling, A., Ketzel, M., Ellermann, T., Lund, R., Sigsgaard, T., Møller, P., Loft, S., (2014). Cardiovascular and lung function in relation to outdoor and indoor exposure to fine and ultrafine particulate matter in middle-aged subjects. Environ. Int. 73, 372-381.

Kim, K.H., Kim, J.B., Ji, J.H., Lee, S.B., Bae, G.N., (2015). Nanoparticle formation in a chemical storage room as a new incidental nanoaerosol source at a nanomaterial workplace. J. Hazard. Mater. 298, 36-45.

Knibbs, L.D., Cole-Hunter, T., Morawska, L., (2011). A review of commuter exposure to ultrafine particles and its health effects. Atmos. Environ. 45, 2611-2622. 
Kura, B., Mookoni, P., (1998). Maximum Achievable Control Technology: What A Shipbuilder Should Know For Environmental Compliance. J. Sh. Prod. 14, 255-264.

Lamble, S.P., Corsi, R.L., Morrison, G.C., (2011). Ozone deposition velocities, reaction probabilities and product yields for green building materials. Atmos. Environ. 45, 6965-6972.

Lamorena, R.B., Jung, S.-G., Bae, G.-N., Lee, W., (2007). The formation of ultra-fine particles during ozone-initiated oxidations with terpenes emitted from natural paint. J. Hazard. Mater. 141, 245-251.

Lamorena, R.B., Lee, W., (2008). Influence of ozone concentration and temperature on ultra-fine particle and gaseous volatile organic compound formations generated during the ozone-initiated reactions with emitted terpenes from a car air freshener. J. Hazard. Mater. 158, 471-477.

Lazaridis, M., Serfozo, N., Chatoutsidou, S.E., Glytsos, T., (2015). New particle formation events arising from painting materials in an indoor microenvironment. Atmos. Environ. 102, 86-95.

Lin, C.-C., Hsu, S.-C., (2015). Deposition velocities and impact of physical properties on ozone removal for building materials. Atmos. Environ. 101, 194-199.

Longhin, E., Pezzolato, E., Mantecca, P., Holme, J.A., Franzetti, A., Camatini, M., Gualtieri, M., (2013). Season linked responses to fine and quasi-ultrafine Milan PM in cultured cells. Toxicol. Vitr. 27, 551-559.

Lonkar, P., Dedon, P.C., (2011). Reactive species and DNA damage in chronic inflammation: reconciling chemical mechanisms and biological fates. Int. J. Cancer 128, 1999-2009.
Loomis, D., Grosse, Y., Lauby-Secretan, B., Ghissassi, F. El, Bouvard, V., BenbrahimTallaa, L., Guha, N., Baan, R., Mattock, H., Straif, K., (2013). The carcinogenicity of outdoor air pollution. Lancet Oncol. 14, 1262-1263.

Lu, S., Yi, F., Hao, X., Yu, S., Ren, J., Wu, M., Jialiang, F., Yonemochi, S., Wang, Q., (2014). Physicochemical properties and ability to generate free radicals of ambient coarse, fine, and ultrafine particles in the atmosphere of Xuanwei, China, an area of high lung cancer incidence. Atmos. Environ. 97, 519-528.

Malherbe, L., Mandin, C., (2007). VOC emissions during outdoor ship painting and health-risk assessment. Atmos. Environ. 41, 6322-6330.

Marchand, C., Bulliot, B., Le Calvé, S., Mirabel, P., (2006). Aldehyde measurements in indoor environments in Strasbourg (France). Atmos. Environ. 40, 1336-1345.

Marion, M., Tiffonnet, A.L., Santa-Cruz, A., Makhloufi, R., (2011). Study of the resistances to transfer of gaseous pollutant between material and indoor air. Build. Environ. 46, 356-362.

Norbäck, D., Wieslander, G., Edling, C., (1995). Occupational exposure to volatile organic compounds (VOCs), and other air pollutants from the indoor application of water-based paints. Ann. Occup. Hyg. 39, 783-794.

Nørgaard, A.W., Kudal, J.D., Kofoed-Sørensen, V., Koponen, I.K., Wolkoff, P., (2014). Ozone-initiated VOC and particle emissions from a cleaning agent and an air freshener: Risk assessment of acute airway effects. Environ. Int. 68, 209-218.

Pandrangi, L.S., Morrison, G.C., (2008). Ozone interactions with human hair: Ozone uptake rates and product formation. Atmos. Environ. 42, 5079-5089. 
Pearson, J.F., Bachireddy, C., Shyamprasad, S., Goldfine, A.B., Brownstein, J.S., (2010). Association between fine particulate matter and diabetes prevalence in the U.S. Diabetes Care 33, 2196-201.

Perrone, M.G., Gualtieri, M., Consonni, V., Ferrero, L., Sangiorgi, G., Longhin, E., Ballabio, D., Bolzacchini, E., Camatini, M., (2013). Particle size, chemical composition, seasons of the year and urban, rural or remote site origins as determinants of biological effects of particulate matter on pulmonary cells. Environ. Pollut. 176, 215227.

Peters, A., Dockery, D.W., Muller, J.E., Mittleman, M.A., (2001). Increased particulate air pollution and the triggering of myocardial infarction. Circulation 103, 2810-5.

Pierucci, S., (2005). An innovative sustainable process for VOCs recovery from spray paint booths*1. Energy 30, 1377-1386.

Pope, C.A., Burnett, R.T., Krewski, D., Jerrett, M., Shi, Y., Calle, E.E., Thun, M.J., (2009). Cardiovascular mortality and exposure to airborne fine particulate matter and cigarette smoke: shape of the exposure-response relationship. Circulation 120, 941-8.

Pope III, C.A., Dockery, D.W., (2006). Health Effects of Fine Particulate Air Pollution: Lines that Connect. 9 J. Air Waste Manag. Assoc 56, 702-742.

Qian, K., Zhang, Y., Little, J.C., Wang, X., (2007). Dimensionless correlations to predict VOC emissions from dry building materials. Atmos. Environ. 41, 352-359.

Quang, T.N., He, C., Morawska, L., Knibbs, L.D., (2013). Influence of ventilation and filtration on indoor particle concentrations in urban office buildings. Atmos. Environ. $79,41-52$.
Samet, J.M., Dominici, F., Curriero, F.C., Coursac, I., Zeger, S.L., (2000). Fine particulate air pollution and mortality in 20 U.S. cities, 1987-1994. N. Engl. J. Med. 343, 1742-9.

Sangiorgi, G., Ferrero, L., Ferrini, B.S., Lo Porto, C., Perrone, M.G., Zangrando, R., Gambaro, A., Lazzati, Z., Bolzacchini, E., (2013). Indoor airborne particle sources and semi-volatile partitioning effect of outdoor fine PM in offices. Atmos. Environ. 65, 205-214.

Schieweck, A., Bock, M.-C., (2015). Emissions from low-VOC and zero-VOC paints Valuable alternatives to conventional formulations also for use in sensitive environments? Build. Environ. 85, 243252.

Schwartz, J., (2001). Is there harvesting in the association of airborne particles with daily deaths and hospital admissions? Epidemiology 12, 55-61.

Semple, S., Garden, C., Coggins, M., Galea, K.S., Whelan, P., Cowie, H., SánchezJiménez, A., Thorne, P.S., Hurley, J.F., Ayres, J.G., (2012). Contribution of solid fuel, gas combustion, or tobacco smoke to indoor air pollutant concentrations in Irish and Scottish homes. Indoor Air 22, 212-23.

Shinohara, N., Kai, Y., Mizukoshi, A., Fujii, M., Kumagai, K., Okuizumi, Y., Jona, M., Yanagisawa, Y., (2009). On-site passive flux sampler measurement of emission rates of carbonyls and VOCs from multiple indoor sources. Build. Environ. 44, 859863.

Spilak, M.P., Frederiksen, M., Kolarik, B., Gunnarsen, L., (2014). Exposure to ultrafine particles in relation to indoor events and dwelling characteristics. Build. Environ. 74, 65-74. 
Uhde, E., Salthammer, T., (2007). Impact of reaction products from building materials and furnishings on indoor air quality- $\mathrm{A}$ review of recent advances in indoor chemistry. Atmos. Environ. 41, 3111-3128.

Van der Sluijs, J.P., Risbey, J.S., Ravetz, J., (2005). Uncertainty assessment of VOC emissions from paint in The Netherlands using the NUSAP system. Environ. Monit. Assess. 105, 229-59.

Vartiainen, E., Kulmala, M., Ruuskanen, T.M., Taipale, R., Rinne, J., Vehkamäki, H., (2006). Formation and growth of indoor air aerosol particles as a result of d-limonene oxidation. Atmos. Environ. 40, 7882-7892.

Vu, T. V, Delgado-Saborit, J.M., Harrison, R.M., (2015). Review: Particle number size distributions from seven major sources and implications for source apportionment studies. Atmos. Environ. 122, 114-132.

Wang, C., Waring, M.S., (2014). Secondary organic aerosol formation initiated from reactions between ozone and surface-sorbed squalene. Atmos. Environ. 84, 222-229.

Wang, H., Morrison, G.C., (2006). OzoneInitiated Secondary Emission Rates of Aldehydes from Indoor Surfaces in Four Homes. Environ. Sci. Technol. 40, 52635268 .

Weschler, C.J., (2009). Changes in indoor pollutants since the 1950s. Atmos. Environ. 43, 153-169.

Weschler, C.J., Hodgson, A.T., Wooley, J.D., (1992). Indoor chemistry: ozone, volatile organic compounds, and carpets. Environ. Sci. Technol. 26, 2371-2377.

Weschler, C.J., Nazaroff, W.W., (2008). Semivolatile organic compounds in indoor environments. Atmos. Environ. 42, 9018-
9040.

Wu, S., Deng, F., Hao, Y., Wang, X., Zheng, C., Lv, H., Lu, X., Wei, H., Huang, J., Qin, Y., Shima, M., Guo, X., (2014). Fine particulate matter, temperature, and lung function in healthy adults: Findings from the HVNR study. Chemosphere 108, 168-174.

Xu, B., Chen, Z., Ma, Q., (2016). Effect of highvoltage electric field on formaldehyde diffusion within building materials. Build. Environ. 95, 372-380.

Xu, Y., Zhang, Y., (2004). A general model for analyzing single surface VOC emission characteristics from building materials and its application. Atmos. Environ. 38, 113119.

Zhang, J., Chen, W., Li, J., Yu, S., Zhao, W., (2015). VOCs and Particulate Pollution due to Incense Burning in Temples, China. Procedia Eng. 121, 992-1000.

Zhang, L.Z., Niu, J.L., (2003). Mass transfer of volatile organic compounds from painting material in a standard field and laboratory emission cell. Int. J. Heat Mass Transf. 46, 2415-2423.

Zhao, J., Xie, Y., Qian, X., Jiang, R., Song, W., (2010). Acute effects of fine particles on cardiovascular system: Differences between the spontaneously hypertensive rats and wistar kyoto rats. Toxicol. Lett. 193, 50-60.

Zhao, P., Siegel, J.A., Corsi, R.L., (2007). Ozone removal by HVAC filters. Atmos. Environ. 41, 3151-3160.

Zhao, W., Hopke, P.K., Gelfand, E.W., Rabinovitch, N., (2007). Use of an expanded receptor model for personal exposure analysis in schoolchildren with asthma. Atmos. Environ. 41, 4084-4096. 